\title{
MAIN BARRIERS AND POSSIBLE ENABLERS OF GOOGLE APPS FOR EDUCATION ADOPTION AMONG UNIVERSITY STAFF MEMBERS
}

\author{
F. I. Amadin ${ }^{1,}$, A. C Obienu ${ }^{2}$ and R. 0. Osaseri ${ }^{3}$ \\ 1, 2, 3 Department of Computer SCIEnCE, University of Benin, P.M.B. 1154, BENin City, Edo State, NigERIA. \\ E-mail addresses: ${ }^{1}$ frankamadin@uniben.edu; ${ }^{2}$ obienuac@gmail.com, ${ }^{3}$ roseline.osaseri@uniben.edu
}

\begin{abstract}
Understanding users' acceptance is a key factor for the development and success of Educational Technologies (ETs), as access to these technologies alone does not guarantee use, nor does it determine the benefit for the intended user. This study aimed to investigate the issue with acceptance and use of Google Apps for Education (GAFE) and examine factors that influence and predict acceptance and use among University of Benin Staff Members. A sample of 200 University staff members took part in the research. The structural equation modeling (SEM) technique was employed to describe the adoption process. The result revealed that GAFE facilitating condition was the most important construct, followed by performance expectancy in explicating the causal process in the model to assess the acceptance and use of Google Apps for Education.
\end{abstract}

Keywords: Education Technology; Google Apps for Education; University Staff Members

\section{INTRODUCTION}

According to Potgier \& Herselman [1], Information and communication technologies (ICTs), are the major driving forces of knowledge-based and globalized societies of a new world era. The accelerated adoption and use of ICTs has resulted in the globalization of knowledge and information resources [2]. [3] Suggests that ICTs are playing an integral role in organizations, more specifically in universities, as higher institutions strive to maintain the goals of quality, efficiency, and effectiveness. Today, ICTs or ETs has provided new options to universities around the world for enhancing teaching and learning.

Universities all over the world are considered to be one of the most important institutions where ETs have to be improved and developed [4]. The revolutionary change which is taking place in information technology, has dramatic effects on the way universities execute their duties of teaching, learning and research, particularly on the creation, dissemination and application of knowledge [5]. It is argued that educational technology in the higher institution can be used to address the changing demands of learning to be more flexible, for the extension of university services to national and international levels, and for more costeffective delivery of university education. The introduction of Educational Technology such as Google
Apps for Education (GAFE) into schools clearly changes the way education is conducted. Google Apps for Education paves the way for a new pedagogical approach, where students are expected to play more active roles than before [6].

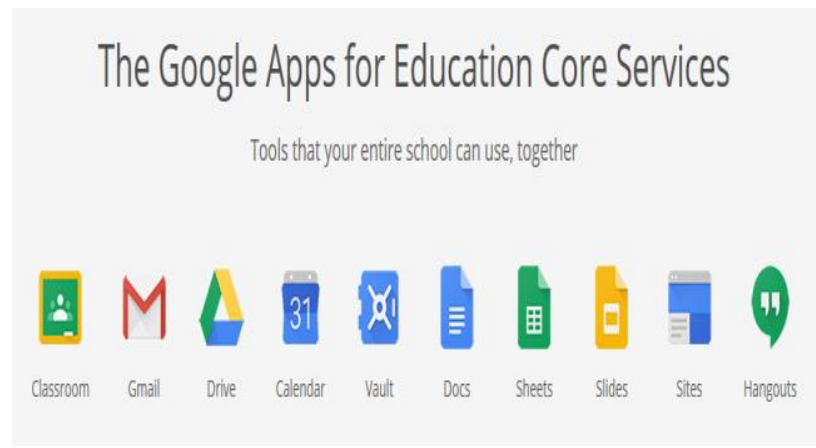

Figure 1: Google Apps Education Edition Suite [7]

GAFE is a free suite of hosted communication and collaboration application, provided by Google for educational institutions. It features several Web applications with parallel functionality to traditional office suites, including Gmail, Google Groups, Google Calendar, Talk, Docs, Slides, Drive, and Sites, for communication and collaborative study anytime, anywhere (See figure 1). It also provides a flexible access to higher education, reducing barriers of time and place of study as well as the size of audiences [4]. 
The acceptance and use of Google Apps for Education by staff members plays an essential and important role in higher institutions. Many studies confirm the importance of staff perception of Educational Technology, which may enhance willingness to accept and facilitate or inhibit use of such innovation. Therefore, staff members' perceptions should be paid great attention, in order to fully understand the dynamics of acceptance and use of Educational Technology in higher institutions [8].

Despite the excellent benefits that come with the Google Apps for Education, there is no empirical and deductive research investigating the factors associated with the acceptance and use of Google Apps for Education by University Staff Members in Nigeria. The University of Benin is looking to the educational possibilities offered by Google Apps for Education as a way to expand and improve its education system. Today, University of Benin is making efforts and planning to enhance Google Apps for Education use among its staff. To this end, this research is designed to understand how University staff members accept and use Google Apps for Education in their professional activities and also to confront the shortage of studies that have explored the Google Apps for Education use among staff Members in Nigeria.

\section{RELATED STUDIES}

Understanding why university staff members accept or reject Educational Technology (such as Google Apps for Education) has been one of the most remarkable issues in the study of technology acceptance research. Access to ETs alone does not ensure use, nor does it determine the benefit for education. The adoption and implementation of ETs by academic organizations is a complex process that requires basic modifications and transformation in the method of thinking and users proficient practices. Currently, technology acceptance is an active space of research where several models and theories have been proposed to understand the drivers of technology adoption.

Several theories and models have been developed to predict and explain factors that influence acceptance of innovations and explain the use of the technology. These models can effectively be used as a theoretical base to understand factors that influence individuals' decisions to use ET. Several education studies were carried out based on these models and reached conclusions about the ability of these models to explain specific situations. After an extensive review of the literature and in the light of the study objectives, the unified theory of acceptance and use of technology
(UTAUT) model was found to be more suitable. In this research, the extended UTAUT introduced by [9] will be used as a theoretical framework to examine the factors that influence university staff members' acceptance and use of Google Apps for Education in their work activities.

UTAUT theorized that an individual's behavioral intention to use a technology is prejudiced by four main factors, namely; Performance Expectancy (PE), Effort Expectancy (EE), Social Influence (SI), and Facilitating Conditions (FC). We adapt these constructs and definitions from UTAUT to the staff technology acceptance and use context. Here, performance expectancy is said to be the degree to which using a technology will provide benefits to staff members in performing certain activities; effort expectancy is the degree of ease associated with staff members' use of technology; social influence is the extent to which staff members perceive that important others (e.g., educational planners and senate members) believe they should use a particular technology; and facilitating conditions refer to staff members' perceptions of the support and resources available to perform a behavior [10]. Also, individual difference variables, namely age, gender, and experience are theorized to moderate various UTAUT relationships. In order to adapt this model for consumers' acceptance and usage of technologies, [9] proposed the extended unified theory of the acceptance and use of technology $\left(\mathrm{UTAUT}_{2}\right.$ ) by adding three new constructs, that is, Hedonic Motivation, Price Value and Habit and new relationships.

UTUAT $_{2}$ has been selected primarily because it was a widely applied model, originally developed and designed for explaining and predicting users' acceptance of an information system [11]. In addition, UTAUT $_{2}$ has turn out to be the latest and most powerful theory to predict and explain an information systems usage intention. This study will adapt UTAUT $_{2}$ model because it is considered as one of the most powerful models in investigating the factors that affect the technology adoption decision of GAFE $[11,12]$. It also addresses the issue of how users accept and use a technology. Ultimately, the UTAUT 2 has been tested for reliability and validity; the obtained results demonstrated that it is a quite reliable and robust model in predicting users' acceptance in many studies. The model constructs have been well tested and proven to be reliable. Finally, UTAUT $_{2}$ has been implemented and validated in a wide range of areas, including educational contexts [12]. In short, besides the previously mentioned advantages of UTUAT2, the 
model is selected because it fits well with the objectives of the current study.

The research's conceptual framework was built upon UTAUT $_{2}$ [9]. The literature is reviewed and modification of $\mathrm{UTUAT}_{2}$ was suggested to serve the study objectives and make it more relevant to the study of the acceptance of Google Apps for Education in Nigeria universities. The price factor was omitted, and other factors such as technology awareness and attitude were added to the UTAUT ${ }_{2}$ model. Accordingly, the research model can be described briefly, as constructed from UTAUT $_{2}$ in addition to two external variables, which are technology awareness and attitude. Technology awareness is the state of consciousness or quality of being aware of a product, technology, or new concept while attitude is an individual's positive or negative feelings (evaluative effect) about performing the target behavior. The model simply assumes that eight major variables influence Google Apps for Education acceptance and use by staff members in the University of Benin. The conceptual model adopted for this study will focus on identifying the relationship between Technology Awareness (TA), Performance Expectancy (PE), Effort Expectancy (EE), Social Influence (SI), Attitude (ATUT), Hedonic Motivation (HM), Habit (HA), Facilitating Conditions (FC) and staff members' intention to use Google Apps for Education.

\section{METHODOLOGY}

\subsection{Research Objectives Are:}

I. To ascertain the level of acceptance of Google Apps for Education among University Staff Members.

II. To investigate on how modified UTAUT $_{2}$ factors influence University staff members to use Google Apps for Education.

200 questionnaires were administered and collected. Using mean rating, correlation analysis and structural equation modeling, the study aims to ascertain the level of acceptance and verify the influence of the eight constructs of modified UTAUT2 (TA, PE, EE, SI, ATUT, HM, HA and FC) on the behavioral intention of the university staff members, towards the acceptance and use of Google Apps for Education which was deployed in their academic environment.

These findings will be used to answer the two research questions raised:

$\mathrm{RQ}_{1}$ : What is the level of acceptance of Google Apps for Education among university staff members?
$\mathrm{RQ}_{2}$ : To what extent modified UTAUT factors influence University staff members to use GAFE?

\section{RESULT ANALYSIS}

\subsection{Study Sample Characteristics}

By analyzing the responses of section A of Google Apps for Education questionnaire and as shown in Table 1, the study sample is appropriate in terms of the diversity of gender, age, academic level, and Units.

Table 1: Demographic Characteristics of Respondents

\begin{tabular}{|c|c|c|c|}
\hline Items & Frequency & Percent (\%) & $\begin{array}{l}\text { Cumulative } \\
\text { Percent (\%) }\end{array}$ \\
\hline \multicolumn{4}{|c|}{ Gender } \\
\hline Male & 111 & 55.5 & 55.5 \\
\hline Female & 89 & 44.5 & 100.0 \\
\hline Total & 200 & 100.0 & \\
\hline \multicolumn{4}{|c|}{ Age Group } \\
\hline $21-25$ & 7 & 3.5 & 3.5 \\
\hline $26-30$ & 59 & 29.5 & 33.0 \\
\hline $31-35$ & 41 & 20.5 & 53.5 \\
\hline $36-40$ & 49 & 24.5 & 78.0 \\
\hline $41 \&$ Above & 44 & 22.0 & 100.0 \\
\hline Total & 200 & 100.0 & \\
\hline \multicolumn{4}{|c|}{ Academic Level } \\
\hline Bachelor & 10 & 5.0 & 5.0 \\
\hline Higher Diploma & 17 & 8.5 & 13.5 \\
\hline Masters & 94 & 47.0 & 60.5 \\
\hline Doctorate & 61 & 30.5 & 91.0 \\
\hline Others & 18 & 9.0 & 100.0 \\
\hline Total & 200 & 100.0 & \\
\hline \multicolumn{4}{|c|}{ Units/Faculty } \\
\hline CRPU/ICT & 10 & 5.0 & 5.0 \\
\hline $\begin{array}{l}\text { Students } \\
\text { Affairs }\end{array}$ & 10 & 5.0 & 10.0 \\
\hline PG School & 10 & 5.0 & 15.5 \\
\hline Library & 10 & 5.0 & 20.0 \\
\hline Agriculture & 13 & 6.5 & 26.5 \\
\hline Art & 13 & 6.5 & 33.0 \\
\hline $\begin{array}{l}\text { Basic Medical } \\
\text { Science }\end{array}$ & 13 & 6.5 & 39.5 \\
\hline Dentistry & 10 & 5.0 & 44.5 \\
\hline Education & 13 & 6.5 & 51.0 \\
\hline Engineering & 13 & 6.5 & 57.5 \\
\hline Law & 10 & 5.0 & 62.5 \\
\hline Life Science & 13 & 5.0 & 69.0 \\
\hline $\begin{array}{l}\text { Management } \\
\text { Science }\end{array}$ & 13 & 6.5 & 75.5 \\
\hline Medicine & 10 & 5.0 & 80.5 \\
\hline Pharmacy & 10 & 5.0 & 85.5 \\
\hline $\begin{array}{l}\text { Physical } \\
\text { Science }\end{array}$ & 16 & 8.0 & 93.5 \\
\hline $\begin{array}{l}\text { Social } \\
\text { Science }\end{array}$ & 13 & 6.5 & 100.0 \\
\hline Total & 200 & 100.0 & \\
\hline
\end{tabular}


Participants for this research comprise of two hundred (200) staff members from various units and faculties within University of Benin in Nigeria. A questionnaire was developed and distributed to the staff members at their respective faculty locations. University staff members were chosen because they have need of Google Apps for Education for effective communication and collaboration with their students and colleagues. Table 1 offers a summary of the participants' demographic data. Out of the 200 respondents, $55.5 \%$ of the respondents were male, and $44.5 \%$ were female. Of the 200 University staff members responding to the questionnaire, the majority (74.5\%) fall within the age group $26-40$, while $78.0 \%$ or 156 are less than 40 years old, which means that the majority are young staff members. The classification of staff members according to the academic level shows that most of the respondents (47\%) were M.Sc holders, followed by $30.5 \%$ Ph.D holders.

\subsection{Reliability Test for Core Construct}

The reliability analysis was conducted for the core constructs using Cronbach's alpha method. As shown in Table 2, A 0.941 (94.1\%) of reliability coefficient for the entire study indicated high consistency in the measures used. All the determinants were all above 0.7 except TA and SI which were above 0.6. In some other studies, it assumed that score greater than .60 is considered acceptable [13]. It is of evidence that the Cronbach's alpha value for the nine variables in this study ranged from 0.63 to 0.90 . Therefore, the questions related to the acceptance and use is highly reliable.

\section{Table 2: Reliability Validity Test for Core Constructs}

\begin{tabular}{lcc}
\hline Core Constructs & $\begin{array}{c}\text { Cronbach's } \\
\text { Alpha }\end{array}$ & $\begin{array}{c}\text { Number of } \\
\text { Items }\end{array}$ \\
\hline $\begin{array}{l}\text { Technology Acceptance } \\
\text { (TA) }\end{array}$ & 0.625 & 3 \\
$\begin{array}{l}\text { Performance } \\
\text { Expectancy (PE) }\end{array}$ & 0.824 & 3 \\
Effort Expectancy (EE) & 0.808 & 3 \\
$\begin{array}{l}\text { Social Influence (SI) } \\
\text { Attitude (ATUT) }\end{array}$ & 0.659 & 3 \\
$\begin{array}{l}\text { Hedonic Motivation } \\
\text { (HM) }\end{array}$ & 0.761 & 3 \\
$\begin{array}{l}\text { Habit (HA) } \\
\text { Facilitating Condition }\end{array}$ & 0.854 & 3 \\
(FC) & 0.899 & 3 \\
$\begin{array}{l}\text { Behavioural Intention } \\
\text { (BI) }\end{array}$ & 0.867 & 3 \\
$\begin{array}{l}\text { Cronbach's Alpha } \\
\text { (Instrument) = 0.941 }\end{array}$ & 0.876 & 3 \\
\hline
\end{tabular}

For the validity analysis, the KMO (Kaiser-MeyerOlkin) values of this study were all greater than 0.6 as shown in Table 3, which is greater than the required minimum value of 0.5 for adequacy [14]. Higher values for this measure indicate the degree of appropriateness of using factor analysis.

Table 3: Validity of Constructs: KMO and Bartlett's Test

\begin{tabular}{l|l|r}
\hline \multirow{2}{*}{ Kaiser-Meyer-Olkin. } & $\begin{array}{l}\text { Measure of } \\
\text { Sampling Adequacy }\end{array}$ & .875 \\
\hline \multirow{2}{*}{$\begin{array}{l}\text { Bartlett's Test of } \\
\text { Sphericity }\end{array}$} & Approx. Chi-Square & 3502.286 \\
\cline { 2 - 3 } & Df & 36 \\
\cline { 2 - 3 } & Sig. & .000 \\
\hline
\end{tabular}

All tests indicated that twenty-seven (27) variables from nine constructs were suitable to carry out the analysis.

\subsection{Research Question One}

What is the level of acceptance of Google Apps for Education among university staff members?

Table 4: Staff Level of Acceptance of Google Apps for Education

\begin{tabular}{lcc}
\hline \multicolumn{1}{c}{ Valid Construct } & Mean Ratinga & Level \\
\hline TA & 4.20 & High \\
PE & 3.67 & Moderate \\
E E & 3.85 & Moderate \\
S I & 3.47 & Moderate \\
A & 4.23 & High \\
H M & 3.58 & Moderate \\
HA & 2.83 & Low \\
F C & 3.95 & Moderate \\
B I & 3.92 & Moderate \\
\hline \multicolumn{2}{r}{ a. Rated on a scale of 1(very low) to 5(very high) }
\end{tabular}

This question examined the level of acceptance of Google Apps for Education by University staff members, which was deployed in their academic environment. To explore their acceptance level, mean ratings were calculated via SPSS 20 . The rating was on a scale interval of 5 (very high) to 1 (very low). The summary of data is stated in Table 4.

From Table 4, it was observed that the overall acceptance of Google Apps for Education by University staff members was moderate. Moderates scores for constructs such as Performance Expectancy, Attitude, Hedonic Motivation, Behavioral Intention and Low score for Habit indicate that University staff members have fairly realized the benefits of using the system; although its usage in their professional activities is not yet a habit to them. Hence, University staff members did not have a high intention to use apps in their professional activities. However, they intend to utilize 
it because of its benefits, which include; reduction of workload, reduction of contact time, improving job performance such as flexibility, efficiency, ease of communication, and ease of assignment collection.

\subsection{Research Question Two}

To what extent modified UTUAT $_{2}$ factors influence University staff members to use Google Apps for Education?

This question examined if modified $\mathrm{UTAUT}_{2}$ factors could help to enhance the usage of Google Apps among university staff members. This research question was first tested using correlation analysis to ascertain the relationship between the independent variables (Technology Awareness, Performance Expectancy, Effort Expectancy, Attitude, Social Influence, Hedonic Motivation, Habit and Facilitating Conditions) and dependent variable (staff members' behavioral intention to use GAFE) via SPSS 20, then followed by Structural Equation Modeling (SEM) via Smart Partial Least Square (Smart-PLS 3.0).

\subsection{Correlation Analysis of Staff Responses}

Correlation analysis is a measure of the degree to which a change in the independent variable will result in a change in the dependent variable. Pearsons' Product-Moment Correlation was used to investigate the relationship between the exogenous variables (Technology Awareness, Performance Expectancy, Effort Expectancy, Attitude, Social Influence, Hedonic Motivation, Habit and Facilitating Conditions) and the endogenous variable (Behavioral Intention).

Table 5 shows the correlation of staff adoption factors. According to the correlation analysis, Technology Awareness, Performance Expectancy, Effort
Expectancy, Social Influence, Attitude, Hedonic Motivations and Facilitating Conditions, was positively correlated with staff members' Behavioral Intention where correlation coefficient was equal to $0.499,0.639$, $0.523,0.563,0.614$ and 0.583 respectively. All of the mentioned correlations were significant at the 0.01 level. However, Habit was observed to have an insignificant correlation with Behavioral Intention where the correlation coefficient was 0.261 .

\subsection{Structural Equation Modeling}

Structural Equation Modeling (SEM) is an analysis approach that uses models to explain relationships between multiple variables while at the same time allowing researchers to use latent factors to represent some concepts more accurately. SEM is considered a confirmatory analysis technique that can be used to test and confirm theories [15]. Therefore, the use of prior theory is important as the researchers have to specify the model before it can be run by the software package. In behavioral research of the Information System (IS) field, Partial Least Square (PLS) has been wholeheartedly accepted as an important statistical method [16]. PLS has become increasingly popular, both in IS research and in other disciplines [17]. Accordingly, Smart-PLS was selected based on [18]. The results of path coefficients, coefficients of determination $\left(\mathrm{R}^{2}\right)$, and results of the test of the hypotheses (T-test and P-values) of the structural model of Google Apps for Education are presented in Figures 2 and 3 respectively. The PLS test helps in detecting the path coefficients of different relations and whether the relation is significant or not.

Table 5: Correlation of Staff Members' Adoption Factors

\begin{tabular}{|c|c|c|c|c|c|c|c|c|c|}
\hline & TA & $\mathrm{PE}$ & $\mathrm{EE}$ & SI & ATUT & $\mathrm{HM}$ & $\mathrm{HA}$ & $\mathrm{FC}$ & $\mathrm{BI}$ \\
\hline TA & 1 & & & & & & & & \\
\hline $\mathrm{PE}$ & $.643^{* *}$ & 1 & & & & & & & \\
\hline EE & $.439 * *$ & $.720 * *$ & 1 & & & & & & \\
\hline SI & $.486^{* *}$ & $.697^{* *}$ & $.563^{* *}$ & 1 & & & & & \\
\hline ATUT & $.461^{* *}$ & $.524^{* *}$ & $.493^{* *}$ & $.547^{* *}$ & 1 & & & & \\
\hline HM & $.557^{* *}$ & $.625^{* *}$ & $.535^{* *}$ & $.505^{* *}$ & $.697^{* *}$ & 1 & & & \\
\hline $\mathrm{HA}$ & $.345^{* *}$ & $.347^{* *}$ & $.070 * *$ & $.316^{* *}$ & $.287^{* *}$ & $.434^{* *}$ & 1 & & \\
\hline $\mathrm{FC}$ & $.458^{* *}$ & $.436^{* *}$ & $.493^{* *}$ & $.327^{* *}$ & $.431^{* *}$ & $.431^{* *}$ & $.268^{* *}$ & 1 & \\
\hline $\mathrm{BI}$ & $.499 * *$ & $.639 * *$ & $.523^{* *}$ & $.563^{* *}$ & $.583^{* *}$ & $.614^{* *}$ & $.261^{* *}$ & $.583^{* *}$ & 1 \\
\hline
\end{tabular}

Note: TA = technology awareness; PE = performance expectancy; EE = effort expectancy; SI = social influence; ATUT = attitude, $\mathrm{HM}=$ hedonic motivation; $\mathrm{HA}=$ habit; $\mathrm{FC}=$ facilitating conditions; $\mathrm{BI}=$ behavior intention. **. Correlation is significant at the 0.01 level (2-tailed). 


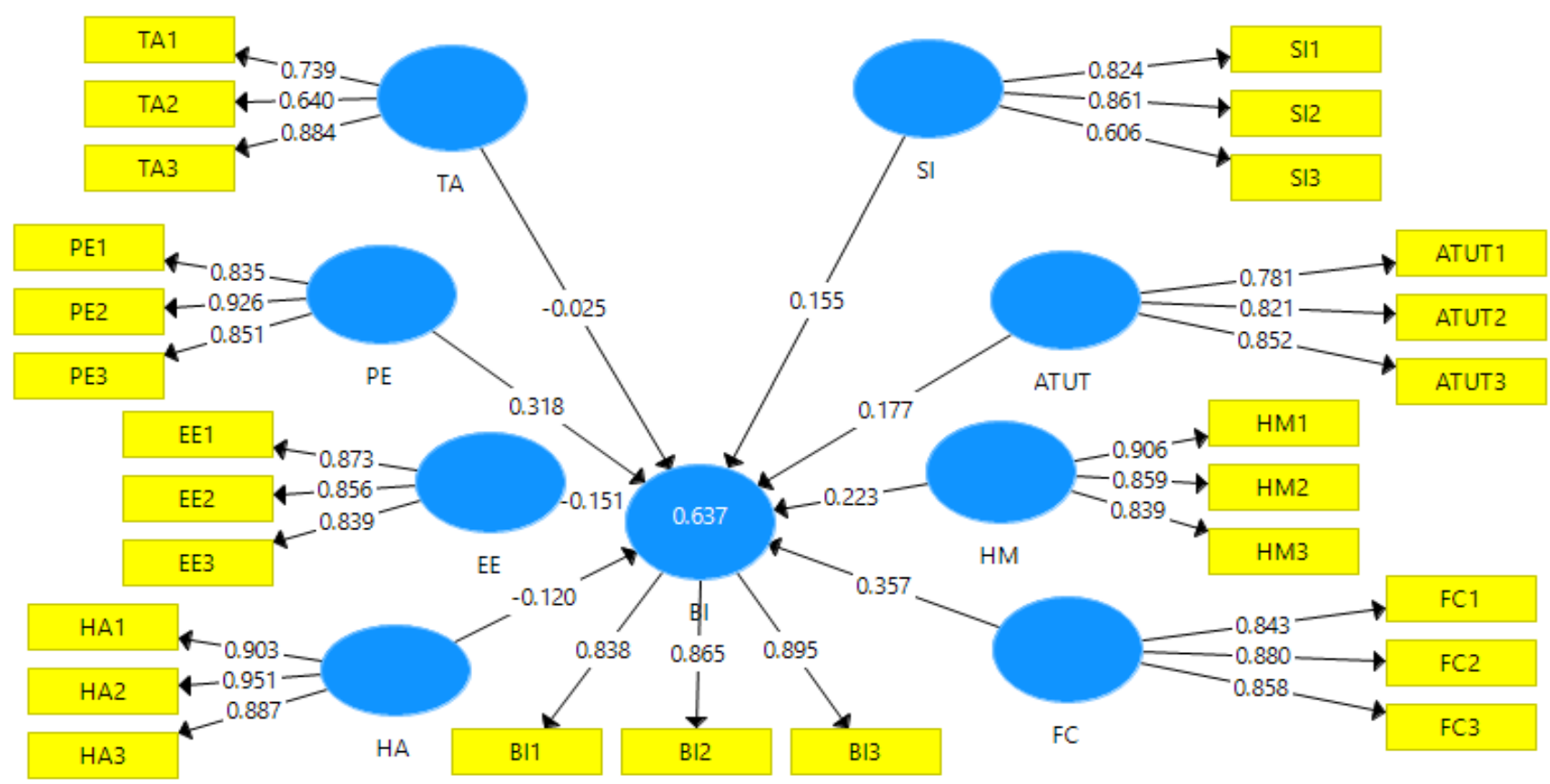

Figure 2: Structural Model of Google Apps for Education

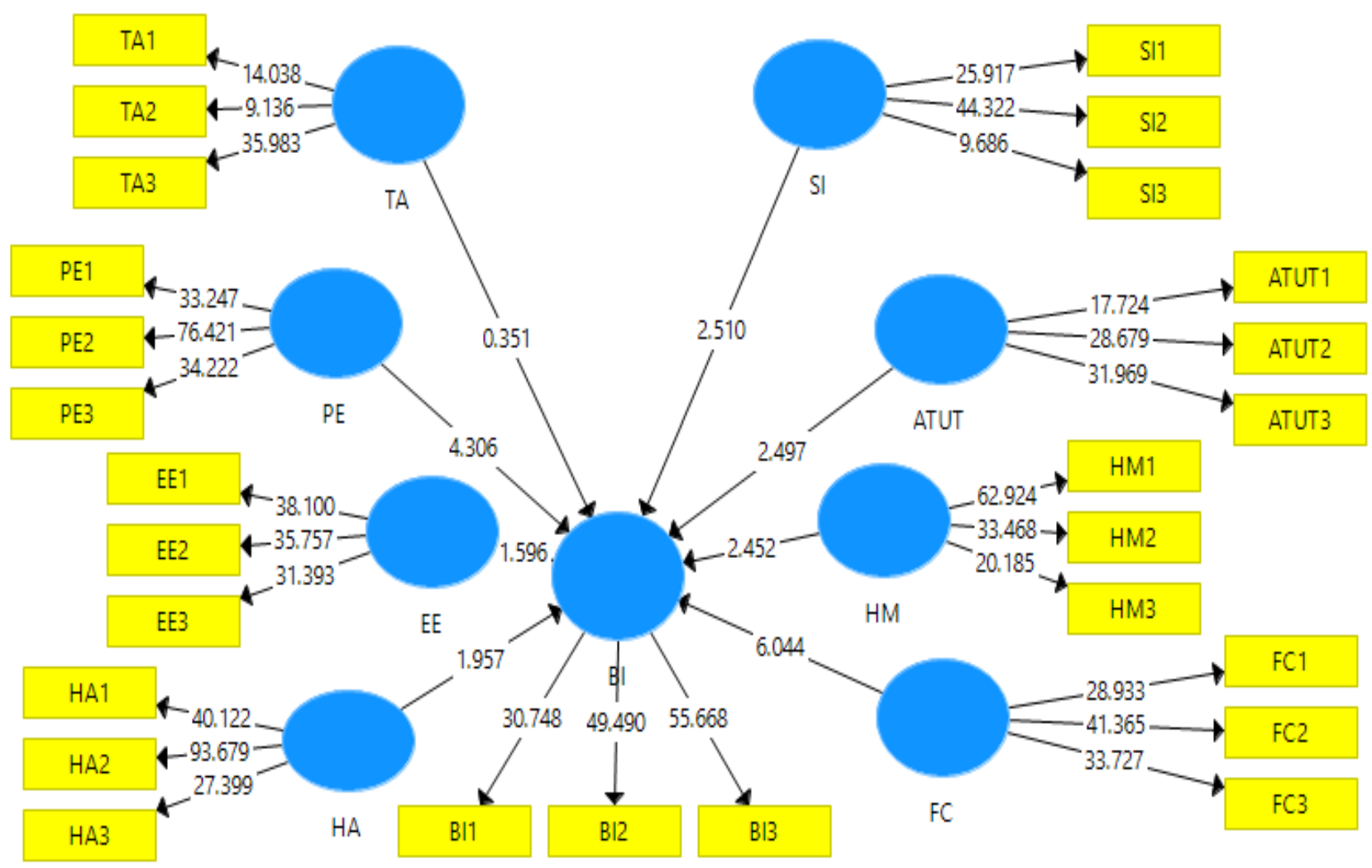

Figure 3: Result of Bootstrapping for the Model of Google Apps for Education

Generally, a high coefficient indicates a significant effect or relation; for example, the relation between FC and BI $(\beta=0.357, \mathrm{t}=6.044)$ denotes the strongest significant positive effect $(\mathrm{p}<0.01)$. A strong positive significant relation was also recognized with regard to the relation between the PE/BI, HM/BI, ATUT/BI, and
SI/BI. Other path coefficients have low values and insignificant relations, which are TA/BI, EE/BI, and HA/BI. This is in line with the previous suggestions on why users do not use technology that is deployed within their academic environment [12]. The coefficient of determination $\left(\mathrm{R}^{2}\right)$ indicates that the 
modified adopted UTAUT model for Google Apps for Education, explains about $63.7 \%$ of the BI to use variance. In other words, $63.7 \%$ of variance in the staff members' BI could be explained by other independent variables (namely FC, PE, HM, ATUT, and SI), which are higher than the average level of prior UTAUT studies regarding intention to use Educational Technology [10].

\subsection{Discussion of Result}

The University of Benin is greatly concerned about the level of acceptance and use of Google Apps for Education, particularly among staff members. The study was designed to address the research problem and answer research questions in other to achieve the research objectives. From the statistical analysis carried out so far, the results obtained in the course of this study have been quite revealing and instructive. This study is assured to have strong reliable determinant to assess University Staff Members' intention in using Google Apps for Education in teaching learning activities. This is based on the result of Cronbach Alpha that was performed by reliability analysis for eight core determinant (independent variables) and one latent construct (dependent variable). The empirical results of our study can provide support for modified UTAUT model.

Furthermore, this study proves a strong and positive relationship between modified UTAUT determinants with University staff members' behavioral intention of using Google Apps for Education in teaching learning activities. The behavioral intention of university staff members was influenced by all determinants except for Technology Awareness (-0.025), Effort efficiency ($0.151)$ and Habit (-0.120). This implies that Staff Members' usage intention of using Google Apps for Education can be improved if the facilitating conditions are made available, fulfillment of hedonic motives, influence of the social circle, their individual habit in using it, and improved level of performance expected by its usage towards improving their professional practices, personal development, and qualitative education.

In comparison to student analysis, the findings indicated that the significant predictors of postgraduate students' intentions to use the system in order of relevance are performance expectancy, facilitating condition, social influence and attitude. Technology awareness, effort expectancy, hedonic motivation and habit have insignificant values since their p-values are greater than 0.05 [12]. Therefore, University authorities should try to develop staff members' intentions to use Google Apps for Education as a supplemental tool for better learning and experience in order to increase actual usage. Factors such as facilitating condition, performance expectancy, hedonic motivation, attitude, and social influence, can all be acted upon in order to improve staff members' usage intentions. Once the staff members' behavioral intention improves, their continuous usage behavior will in turn influence their students' usage behavior for effective collaboration and personal development.

\section{CONCLUSION}

The research result proved UTAUT to be a good theoretical tool to understand staff members' adoption of Google Apps for Education. The UTAUT model shows that staff members' use behavior of Google Apps for Education depends on facilitating condition, performance expectancy, hedonic motivation, attitude, and social influence. Therefore, we suggest that university administrators should provide the right environment before deploying such system. If the 21stcentury learner is to succeed in a fast-changing world even the tools used in disseminating instruction and passing information by staff members has to be one of a modern interface. Thus, it is paramount to educate the technology users on what is expected from the new technology, to increase their levels of compliance. This study is an exploratory study of UTAUTs particularly in educational technology adoption in the higher institution in developing countries. However, it is quite difficult to be generalized since the study only examines the acceptance and use of Google Apps for Education among university staff members. Therefore, we suggest that further study should consider both university staff and students in other Nigerian Universities to validate the findings.

\section{REFERENCES}

[1] Potgier, C., and Herselman, M. Using ICT in tertiary education do we dare to compare, proceedings of the 16th Annual NACCQ Palmerston North New Zealand, (Eds). www.naccq.ac.nz . Accessed 15 September, 2017. 2003.

[2] Islam, M. S., and Islam, M. N. Use of ICT in libraries: An empirical study of selected libraries in Bangladesh, Library Philosophy and Practice, accessed 7 Novermber, 2017. http://tojde.anadolu.edu.tr/tojde21/articles/isla $\underline{\text { m.htm }} 2007$.

[3] Petrides, L. A. Cases on Information Technology in Higher Education: Implications for Policy and 
Practice. Information Science Publishing, London, 2000, p.47-48, 2000.

[4] Brown, I. Individual and technology factors affecting perceived ease of use of web based learning technologies in developing country, the electronic journal on information system in developing countries, vol. 9(5), pp. 1-15.2002,

[5] Herselman, M., and Hay, H. Challenges posed by information and communication technologies (ICT) for South African higher education institutions, university of the free State, bloemfontein, South Africa informing science In SITE, where parallels intersect.http://proceedings.informingscience.org /IS2003Proceedings/docs/119Herse.pdf, 2003,

[6] Alabi. Evolving Role of ICT in Teaching, Research and publishing. Nigeria Tribunal, 30-31. 2004.

[7] Google Inc,"Google Apps for education - free hosted email (Gmail) for EDU," [Online], Accessed April 27, 2016, http://www.google.com/a/help /intl/en/edu/index.html, 2010

[8] Almobarraz, A. Perceived attribute of diffusion of innovation theory as predictor of internet adoption among the faculty 'members of Imam Mohamed Bin Saud University, PhD Thesis, University of North Texas. 2007,

[9] Venkatesh, A., Morris, M. G., and Davis, G. B. User acceptance of information technology: Toward a unified view, MIS Quarterly, vol. 27(3), pp. 425478, 2003.

[10] Venkatesh, V; Thong, L.; and Xu, X. Consumer Acceptance and Use Of Information Technology: Extending The Unified Theory of Acceptance and Use Of Technology. MIS QuarterlyVol. 36 No. 1 pp. 157-178. 2012.

[11] Yamin, M. and Lee, Y. "Level of Acceptance and Factors Influencing Students' Intention to Use
UCSI University's E-mail System". International Conference on User Science and Engineering, 2010.

[12] Amadin, F. I. and Obienu, A. C. "Intention to Use University E-mail System based on Modified UTAUT Model: Perspectives of University of Benin Postgraduate Students". Proceedings of the 6th iSTEAMS Multidisciplinary Cross_Border Conference, University of Professional Studies, Accra Ghana March 2016. Pp 621-628 2016.

[13] Oye, N. D., Iahad, A. N., and Rahim, Ab. N. Acceptance and usage of ICT by university academicians using UTAUT Model: A case study of university of Port Harcourt, Nigerian journal of Emerging Trends in Computing and Information Sciences, vol. 3(1), 2012.

[14] Salim, B. An Application of UTAUT Model for Acceptance of Social Media in Egypt: A Statistical Study. International Journal of Information Science, 2(6): 92-105, 2012.

[15] Hair, J. F., Hult, G. T. M., Ringle, C. \& Sarstedt, M. A Primer on partial least squares structural equation modelling (PLS-SEM). Sage Publications., 2013.

[16] Goodhue, D., Lewis, W., and Thompson, R. PLS, Small sample size, and statistical power, MIS research, paper presented at the 39th Hawaii International Conference on System Sciences. 2006.

[17] Urbach, N., and Ahlemann, F. Structural equation modelling in information systems: Research Using Partial Least Squares, Journal of Information Technology Theory and Application, vol. 11(2), pp. 5 - 40, 2010,

[18] Ringle, C.M., Wende, S., and Will, S. , SmartPLS 2.0 (M3) Beta, Hamburg. http://www.smartpls.de Accessed on February 5, 2016. 2005. 